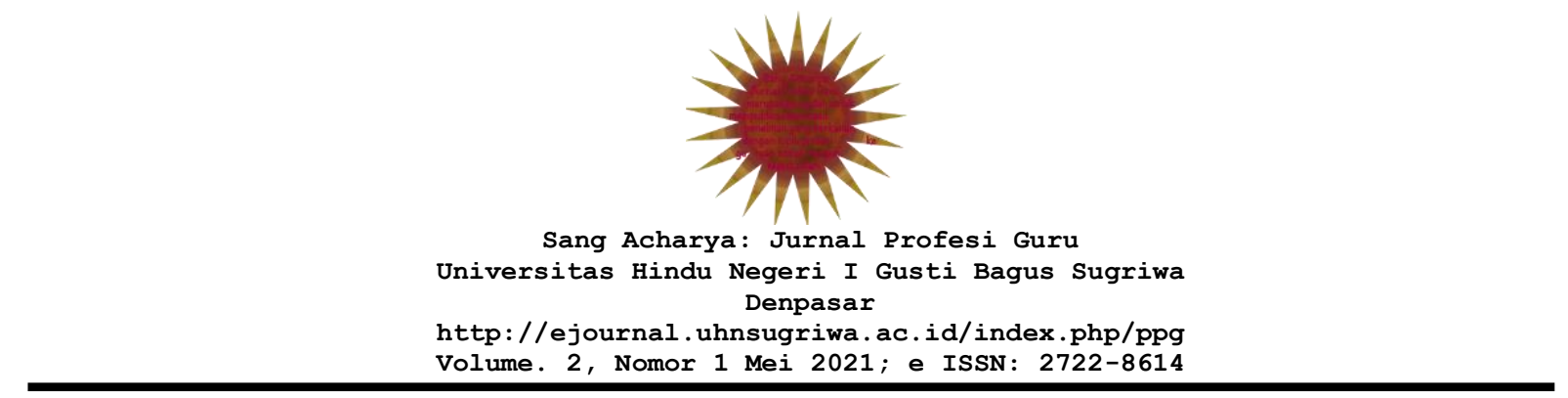

\title{
PERAN GURU IPS MENINGKATKAN KEMAMPUAN BERPIKIR KRITIS SISWA MELALUI METODE PEMBELAJARAN INKUIRI
}

\author{
I Ketut Manik Asta Jaya \\ Universitas Hindu Negeri I Gusti Bagus Sugriwa Denpasar \\ astajayaketut@uhnsugriwa.ac.id
}

Diterima 5 April 2021, direvisi 10 April 2021, diterbitkan 1 Mei 2021

\begin{abstract}
Abstrak
Teachers play a big role in developing and maintaining students' critical thinking skills. This is important so that they are ready and able to face various personal and social problems that exist in life. This study uses literature study to examine more deeply the role of teachers in improving students' critical thinking skills. Research with this literature study, not only collects, reads, and records literature only, but researchers pay attention to the steps in examining literature, especially those related to the role of teachers in optimizing the teaching and learning process in the classroom. This study also examines more deeply about the application of the inquiry learning model to improve students' critical thinking skills. This learning model emphasizes the thinking process of students critically and analytically, to seek and find their own answers to a question in question. This learning process can be done through question and answer between teachers and students. The inquiry learning model can be a student-centered strategy, for example groups of students in inquiry learning are directed to an issue or seek answers to the content of questions through a procedure outlined clearly and structurally by the teacher.
\end{abstract}

\begin{abstract}
Abstrak
Guru memegang peran besar dalam mengembangkan dan melaith kemampuan berpikir kritis siswa. Hal ini penting agar mereka siap dan mampu menghadapi berbagai persoalan personal maupun sosial yang ada dalam kehidupan. Penelitian ini menggunakan studi pustaka untuk mengkaji lebih dalam tentang peran guru dalam meningkatkan kemampuan berpikir kritis siswa. Penelitian dengan studi pustaka ini, tidak hanya mengumpulkan, membaca, dan mencatat literatur saja, tetapi peneliti memperhatikan langkah-langkah dalam meneliti literatur, terutama yang berkaitan dengan peran guru dalam mengoptimalkan proses belajar mengajar di kelas. Penelitian ini juga mengkaji lebih dalam tentang penerapan model pembelajaran inkuiri guna meningkatkan kemampuan berpikir kritis siswa. Model pembelajaran ini menekankan pada proses berpikir siswa secara kritis dan analitis, untuk mencari dan menemukan sendiri jawaban dari suatu masalah yang dipertanyakan. Proses pembelajaran ini bisa dilakukan melalui tanya jawab antara guru dan siswa. Model Pembelajaran inkuiri dapat menjadi suatu strategi yang berpusat pada siswa, misalnya
\end{abstract}




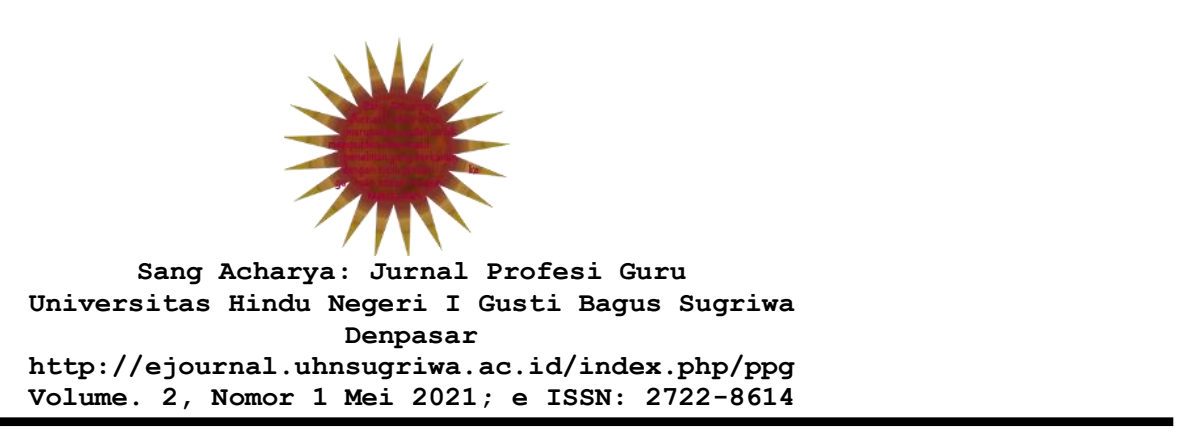

siswa untuk menganalisis pikirannya dalam menentukan pilihan dan menarik kesimpulan dengan cerdas. Apabila siswa diberi kesempatan untuk menggunakan pemikiran dalam tingkatan yang lebih tinggi di setiap tingkatan kelas, maka siswa akan terbiasa membedakan antara kebenaran dan kebohongan, penampilan dan kenyataan, fakta dan opini, pengetahuan dan keyakinan (Kurniawati dkk, 2009).

Berdasarkan uraian diatas dapat diketahui bahwa penting bagi peserta didik memiliki keterampilan berpikir kritis. Kemampuan berpikir kritis merupakan keterampilan yang diperlukan, terutama untuk menghadapi berbagai tantangan zaman. Keterampilan itu meliputi kemampuan berpikir kritis, kreatif dan kemampuan pemecahan masalah. Guru memiliki tanggung jawab besar untuk mengembangkan keterampilan berpikir kritis. Peran guru dalam proses pendidikan menjadi penentu perkembangan peserta didik, terutama dalam membentuk pribadi siswa secara baik. Seorang guru juga memiliki seni tersendiri dalam memodifikasi proses pembelajaran, agar anak didik tidak bosan khususnya saat mengikuti mata pelajaran IPS. Guru yang mampu membangun atmosfer menyenangkan dalam proses belajar mengajar di kelas, akan menarik minat siswa untuk belajar dan memperdalam materi pelajaran. Penting untuk meciptakan suasana pembelajaran yang menyenangkan, nyaman dan jauh dari prilaku menyakitkan perasaan siswa.

Guru sebagai tenaga pendidik profesional berkewajiban untuk mampu menciptakan proses pembelajaran yang melatih kemampuan berpikir kritis siswa. Pemilihan model pembelajaran yang tepat akan mengaktifkan seluruh potensi yang dimiliki siswa, pada akhirnya peserta didik dapat meningkatkan kemampuan berpikir kritis. Berbagai model pembelajaran juga dapat diterapkan dalam upaya meningkatkan kemampuan berpikir kritis peserta didik, diantaranya model pembelajaran inkuiri terbimbing. Model pembelajaran ini dapat meningkarkan kemampuan berpikir kritis siswa. Inkuiri merupakan salah satu model pembelajaran yang tepat dimanfaatkan guru IPS dalam meningkatkan kemampuan berpikir kritis siswa. Model pembelajaran inkuiri bisa dijalankan melalui dialog tanya jawab antara guru dengan siswa. Tetunya, proses dalam model pembelajaran ini lebih terpusat pada siswa, sebab dalam proses pembelajaran ini siswa memegang peran yang dominan. Sementara guru hanya berperan sebagai fasilitator dalam proses pembelajaran, jadi bukan memberi informasi atau ceramah kepada siswa. Trianto (2015) menyatakan bahwa inkuiri tidak hanya mengembangkan kemampuan intelektual tetapi seluruh potensi yang ada, termasuk pengembangan emosional dan keterampilan inkuiri merupakan suatu proses yang bermula dari perumusan masalah, hipotesis, pengumpulan data, menganalisis data dan membuat kesimpulan. Pendekatan inkuiri dapat menjadi salah satu cara untuk mengatasi masalah kebosanan siswa dalam belajar di kelas, karena proses belajar dengan model ini lebih terpusat 


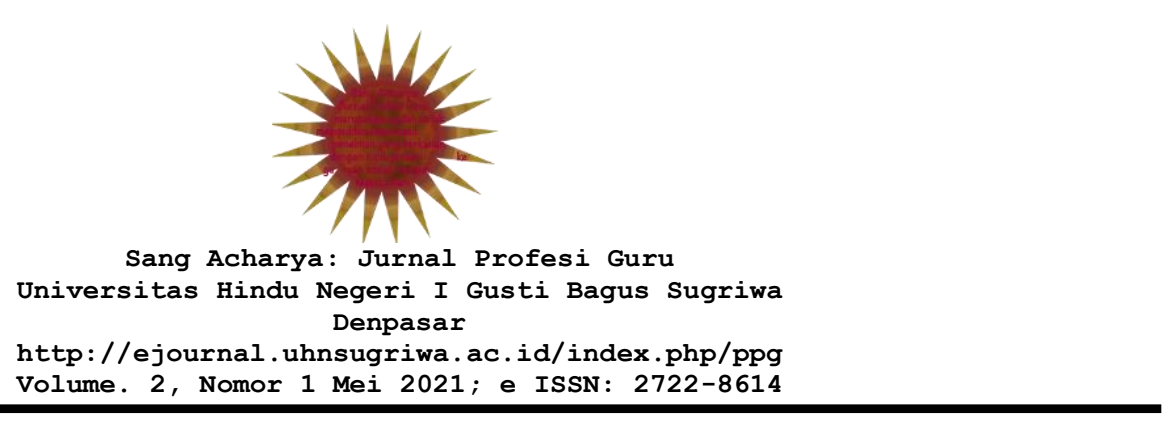

kepada siswa dari pada guru. Berdasarkan definisi tersebut dapat diartikan bahwa inkuiri sebagai suatu model pembelajaran yang dapat mendorong semangat belajar siswa, serta melatih siswa untuk berpikir kritis dan analitis.

Meningkatkan minat belajar siswa, guru IPS juga perlu untuk mengungkapkan kondisi dunia yang semakin berkembang pesat, termasuk pula berbagai persoalan global yang kini menjadi tantangan yang harus dihadapi. Tentunya penjabaran tersebut juga disesuaikan dengan tingkat belajar peserta didik. Perkembangan situasi dunia akan menuntut adanya respons dari peserta didik sebagai warga negara dengan pemikiran kritis. Oleh karena itu, pembelajaran dengan penerapan keterampilan berpikir kritis di kelas merupakan jawaban untuk menyikapi tantangan tersebut.

Persoalan lain yang dihadapi guru IPS ialah minimnya sarana parasarana seperti laboratorium IPS yang belum ada di sekolah, membuat siswa semakin tidak bersemangat dan kurang tertarik untuk belajar. Laboratoriom yang harusnya memuat berbagai miniatur dunia dapat menjadi media pembelajaran yang meningkatkan minat belajar siswa. Menyikapi keterbatasan ini guru IPS mesti cerdas dalam memilih model pembelajaran di kelas, yang dapat menarik minat siswa untuk belajar, dan pada akhirnya dapat memacu siswa untuk berpikir reflektif. Proses pembelajaran IPS layaknya juga disesuaikan dengan kondisi masing-masing peserta didik, agar apa yang dipelajari dapat diterima dengan lebih baik.

Berdasarkan uraian tersebut diketahui bahwa guru IPS memiliki peran besar dalam mengarahkan siswa saat proses belajar. Termasuk juga dalam menarik minat siswa untuk belajar, serta mengasah pola berpikir siswa dalam merespon setiap materi pelajaran yang dikorelasikan dengan fenomena yang ada. Model pembelajaran yang dipilih guru tentunya akan menjadi penentu terhadap hasil belajar para peserta didik. Optimalisasi terhadap proses belajar mengajar tersebut bertujuan melatih kemampuan siswa dalam berpikir kritis. Keterampilan berpikir kritis penting dimiliki setiap generasi muda, agar memiliki kemampuan dalam menyikapi fenomena serta berbagai persoalan sosial.

\section{METODE}

Penelitian ini menggunakan studi pustaka, dimana peneliti mengkaji mengenai konsep dan teori yang digunakan berdasarkan referensi atau literatur yang tersedia, terutama dari artikel-artikel yang dipublikasikan dalam berbagai jurnal ilmiah (Sugiyono, 2015). Studi ini merujuk pada penelitian kajian pustaka yang terkait dengan peranan guru dalam meningkatkan kemampuan berfikir kritis siswa melalui metode pembelajaran inkuiri. Dalam hal ini peneliti tetap memperhatikan langkah-langkah dalam meneliti literatur. Beberapa langkah yang mesti diperhatikan seperti metode penelitian untuk mengumpulkan data, 


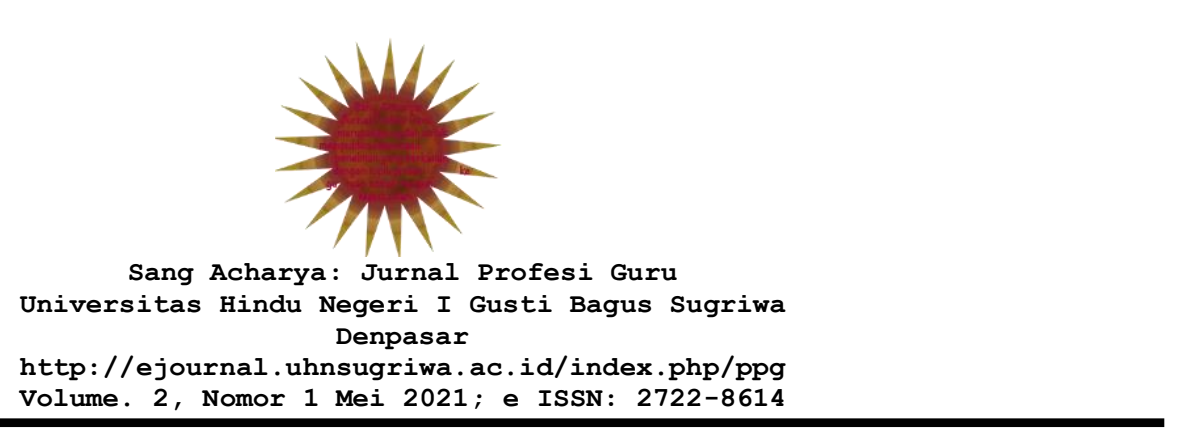

membaca dan mengolah bahan pustaka. Peneliti melihat pentingnya peran guru dalam membantuk mengembangkan kemampuan berfikir kritis siswa pada mata pelajaran IPS, terutama dalam menanggapi berbagai kondisi lingkungan dan sosial. Guru juga berperan dalam membimbing siswa mengenal potensi, memupuk rasa percaya diri dan cara membina hubungan atau bersosialisasi dengan orang lain, sehingga peran guru IPS sangat penting dalam membimbing pertumbuhan dan perkembangan kecerdasan siswa.

\section{PEMBAHASAN}

\subsection{Hakikat Mata Pelajaran IPS}

Mata pelajaran IPS sudah mulai dipelajari siswa sejak dibangku sekolah dasar. Tidak hanya di sekolah dasar, IPS sebagai ilmu yang bersifat interdisipliner juga diajarkan hingga di perguruan tinggi. Menurut pasal 37 UU RI No. 20 Tahun 2003 dinyatakan bahwa mata pelajaran IPS merupakan salah satu bagian dari kurikulum pendidikan dasar dan menengah. IPS yang diajarkan pada pendidikan dasar dan menengah, menjadi pengantar bagi pembelajaran IPS ataupun ilmu sosial di perguruan tinggi. Selain itu, IPS dapat dirumuskan atas dasar realitas dan fenomena sosial yang mewujudkan suatu pendekatan interdisipliner dari aspek dan cabang-cabang ilmu sosial.

Penanaman pendidikan IPS sejak sekolah desar penting untuk mengembangkan potensi peserta didik, agar peka terhadap masalah sosial yang terjadi di masyarakat, memiliki sikap mental positif terhadap perbaikan segala ketimpangan yang terjadi, terampil mengatasi setiap masalah yang terjadi sehari-hari baik yang menimpa dirinya sendiri maupun masyarakat. Dari tujuan IPS tersebut agar peserta didik dapat: (1) memiliki kesadaran dan kepedulian terhadap nilai-nilai sejarah dan kebudayaan masyarakat; (2) mengetahui dan memahami konsep dasar dan mempu menggunakan metode yang diadopsi dari ilmu-ilmu sosial dan digunakan untuk memecahkan masalah; (3) memperhatikan isu-isu dan masalahmasalah sosial dan membuat analisis secara kritis; (4) mengembangkan berbagai potensi untuk membangun diri sendiri agar survive di tengah era globalisasi; (5) mampu berkompetisi dan berpartisipasi dalam masyarakat (Yulia, 2018:25).

Berdasarkan penjabaran tersebut dapat diartikan bahwa IPS sebagai bidang studi yang mempelajari tentang menelaah, menganalisis, gejala dan masalah sosial di masyarakat dengan meninjau dari berbagai aspek kehidupan atau perpaduan. IPS sebagai bidang studi memiliki garapan yang dipelajari cukup luas meliputi gejala-gejala dan masalah kehidupan manusia di masyarakat. Mata pelajaran IPS pada hakikatnya merupakan suatu integrasi utuh dari disiplin ilmu-ilmu sosial dan disiplin ilmu lain yang relevan untuk merealisasikan tujuan pendidikan di tingkat persekolahan. Implikasinya berbagai tradisi dalam ilmu sosial termasuk konsep, struktur, aspek metode, maupun aspek nilai yang dikembangkan dalam ilmu-ilmu sosial, dikemas secara psikologis, pedagogis dan sosial budaya untuk kependingan pendidikan.

Yulia (2018:21) menjabarkan bahwa IPS untuk jenjang pendidikan di sekolah terdiri dari dua versi akademis pedagogis. Pertama, IPS dalam tradisi "citizenship transmission" dalam bentuk mata pelajaran Pendidikan Pancasila dan Kewarganegaraan dan Sejarah 


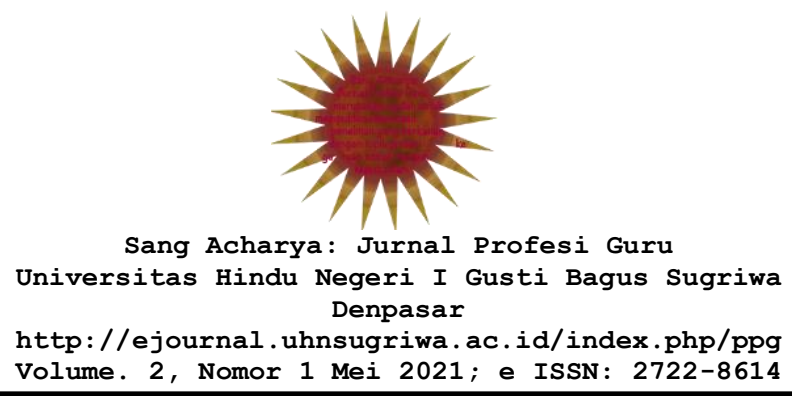

Indonesia. Kedua IPS dalam tradisi "Sosial sciences" dalam pata pelajaran IPS terpadu untuk SD dan mata pelajaran IPS terkonfederasi untuk SLTP, serta IPS terpisah untuk SMU. Kedua tradisi IPS tersebut terikat oleh suatu visi pengembangan manusia Indonesia seutuhnya sebagaimana digariskan dalam GBHN dan UU No. 2/1989 tentang Sistem Pendidikan Nasional. Dalam kontek perkembangan pendidikan "social studies" di Amerika atau Pendidikan IPS di Indonesia konsep dan praksis pendidikan demokrasi yang dikemas sebagai "citizenship education" atau "Pendidikan Kewarganegaraan" berkedudukan sebagai salah satu dimensi dari tujuan, konten dan proses social studies atau pendidikan IPS. Dapat dikatakan pendidikan demokrasi merupakan salah satu subsistem dalam sistem pembelajaran social studies atau pendidikan IPS. Meski demikian sussistem pendidikan demokrasi sejak awal perkembangannya menunjukkan keunikan dan kemandiriannya sebagai program pendidikan yang ditujukan untuk mengembangkan warga negara yang cerdas dan bernurani.

Dalam proses pembelajaran IPS, siswa dapat dibawa langsung ke dalam lingkungan alam dan masyarakat. Upaya ini akan berdampak terhadap peserta didik, dengan belajar langsung melihat lingkungan alam sekitar, siswa akan akrab dengan kondisi setempat. Melalui upaya ini siswa lebih mengetahui makna serta manfaat mata pelajaran IPS secara nyata. Manfaat yang diperoleh setelah mempelajari IPS disamping mempersiapkan diri untuk terjun ke masyarakat. Proses pembelajaran ini juga membentuk pribadi peserta didik sebagai anggota masyarakat yang baik, dengan menaati aturan yang berlaku dan turut pula mengembangkannya. Peserta didik juga secara langsung bermanfaat dalam mengembangkan pendidikanya ke jenjang yang lebih tinggi.

Handayani (2014: 15) menyatakan pembelajaran IPS akan berhasil dengan baik apabila guru dapat memperhatikan cultural background dan cultural diversity. Mempertimbangkan hal itu, dalam proses pembelajaran penting untuk mengasah pengalaman dan latar belakang peserta didik sebagai landasan dasar, serta untuk memahami setiap permasalahan yang dihadapi. Proses pembelajaran akan lebih berhasil apabila didasari oleh pengalaman-pengalaman pribadi peserta didik secara faktual dan konkret. Peserta didik belajar IPS diawali dari lingkungan sekitar, menyangkut aspek geografi, ekonomi, sejarah, antropologi, pemerintahan dan lainya. Dalam membangun suatu konsep dimulai dengan proses asimilasi. Selanjutnya apabila sudah mantap berlanjut kepada jenjang berikutnya, yaitu proses adaptasi.

Proses pembelajaran IPS akan dapat berhasil apabila guru memiliki bekal pengetahuan, formula IPS dan karakteristik IPS itu sendiri. Pemahaman guru tentang konsep dan karakteristik pelajaran IPS merupakan modal penting untuk membimbing belajar peserta didik dalam pembelajaran IPS. Guru juga mesti pandai memilah waktu, ditengah keterbatasan waktu dalam proses belajar mengajar, hal ini mengingat luasnya materi pelajaran IPS, sehingga dapat terpenuhi aspek keluasan dan kedalaman materi.

\subsection{Peran Guru IPS Menerapkan Model Pembelajaran Inkuiri}

Guru dalam menjalankan proses belajar di kelas tidak dapat terlepas dari persiapan model pembelajaran. Model pembelajaran sebagai konseptual yang melukiskan prosedur 


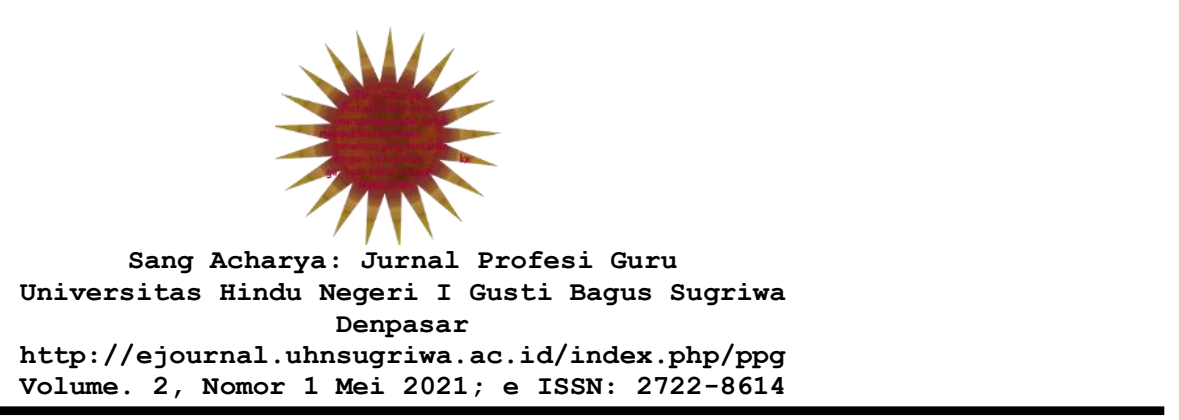

sistematis dalam mengorganisasikan pengalaman belajar untuk mencapai tujuan belajar. Model pembelajaran mempunyai makna yang lebih luas dari pada suatu strategi pembelajaran, metode atau prosedur pembelajaran. Penguasaan dan penerapan model pembelajaran yang tepat dalam proses belajar mengajar menjadi bagian yang esensiil untuk mencapai tujuan pendidikan. Model pembelajaran yang baik memerlukan sikap guru yang akurat, artistik, berkepribadian dan selalu menyesuaikan dengan tingkat pengalaman siswa. Model pembelajaran yang baik haruslah melibatkan partisipasi guru dan murid. Salah satu model pembelajaran untuk mengatasi kebosanan siswa belajar di kelas karena pengajaran terlalu didominasi oleh pendekatan ekspositori (ceramah) yang berpusat pada guru adalah model pembelajaran inkuiri.

Model Pembelajaran inkuiri menjadi salah satu metode belajar yang menekankan pada proses berpikir secara kritis dan analitis, untuk mencari dan menemukan sendiri jawaban dari suatu masalah yang dipertanyakan. Proses berpikir itu sendiri biasanya dilakukan melalui tanya jawab antara guru dan siswa. Model Pembelajaran inkuiri dapat menjadi suatu strategi yang berpusat pada siswa, dimana kelompok siswa pembelajaran inkuiri diarahkan ke suatu isu atau mencari jawaban-jawaban terhadap isi pertanyaan melalui suatu prosedur yang digariskan secara jelas dan struktural kelompok. Dari rumusan tersebut, yang dimaksud dengan pembelajaran inkuiri dalam penelitian ini adalah rangkaian kegiatan pembelajaran yang menuntut siswa untuk mencari sendiri jawaban-jawaban dari masalah yang dipertanyakan sehingga terbentuk suatu konsep dalam diri siswa tentang materi yang dipelajari.

Pembelajaran inkuiri bertujuan untuk menolong siswa agar dapat mengembangkan disiplin intelektual dan keterampilan berpikir dengan memberikan pertanyaan-pertanyaan dan mendapatkan jawaban atas dasar rasa ingin tahu mereka. Pembelajaran inkuiri merupakan bentuk dari pendekatan pembelajaran yang berorientasi kepada siswa (student centered approach). Dikatakan demikian, sebab dalam pembelajaran inkuiri ini siswa memegang peran yang sangat dominan dalam proses pembelajaran. Peran guru dalam proses pembelajaran ini ialah sebagai fasilitator, jadi tidak semata memberikan informasi atau ceramah pada siswa. Guru juga harus menfokuskan pada tujuan pembelajaran, yaitu mengembangkan tingkat berpikir yang lebih tinggi dan keterampilan berpikir kritis siswa, setiap pertanyaan yang diajukan siswa sebaiknya tidak langsung dijawab oleh guru. namun siswa diarahkan untuk berpikir tentang jawaban dari pertanyaan tersebut.

Trianto (2015: 137) menyatakan, bahwa inkuiri tidak hanya mengembangkan kemampuan intelektual tetapi seluruh potensi yang ada. termasuk pengembangan emosional dan keterampilan. Inkuiri merupakan suatu proses yang bermula dari perumusan masalah, merumuskan hipotesis pengumpulan data, menganalisis data, dan membuat kesimpulan. Model pembelajaran inkuiri akan efektif apabila; 1) Guru mengharapkan siswa dapat menemukan sendiri jawaban dari suatu permasalahan yang ingin dipecahkan. Dengan demikian dalam pembelajaran inkuiri penguasaan materi pelajaran bukan sebagai tujuan utama pembelajaran, akan tetapi yang lebih dipentingkan adalah proses belajar. 2) Jika bahan pelajaran yang akan disampaikan tidak berbentuk fakta atau konsep yang sudah jadi, akan 


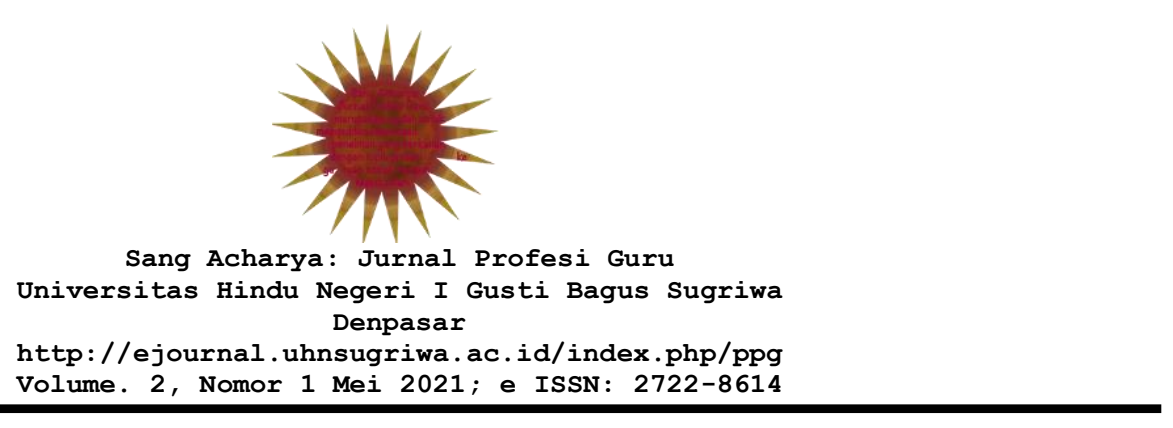

tetapi sebuah kesimpulan yang perlu pembuktian. 3) Jika proses pembelajaran berangkat dari rasa ingin tahu siswa terhadap sesuatu. 4) Jika guru akan mengajar pada sekelompok siswa yang rata-rata memiliki kemauan dan kemampuan berpikir. 5) Jika jumlah siswa yang belajar tidak terlalu banyak, sehingga bisa dikendalikan oleh guru. 6) Jika guru memiliki waktu yang cukup untuk menggunakan pendekatan yang berpusat pada siswa.

Terdapat sejumlah ciri-ciri dari pebelajaran inkuri dalam proses belajar mengajar, yang dapat diterapkan oleh pendidik. Adapun ciri-ciri pebelajaran inkuiri yakni: 1) menekankan pada aktivitas siswa secara maksimal untuk mencari dan menemukan sendiri jawaban dari suatu masalah yang dipertanyakan, artinya dalam pembelajaran inkuiri menempatkan siswa sebagai subjek belajar. 2) Seluruh aktifitas siswa diarahkan untuk mencari dan menemukan jawaban sendin dari sesuatu yang dipertanyakan, sehingga diharapkan dapat menumbuhkan sikap percaya diri (self belre), dengan demikian pembelajaran inkuiri menempatkan guru bukan sebagai sumber belajar, akan tetapi sebagai fasilitator dan motivator belajar siswa. 3) Mengembangkan kemampuan berpikir secara sistematis, logis, dan kritis mengembangkan kemampuan intelektual sebagai bagian dari proses mental. Dengan demikian, dalam pembelajaran inkuiri siswa tidak hanya dituntut agar menguasai materi pelajaran, akan tetapi bagaimana mereka dapat menggunakan potensi yang dimilikinya (Marhaeni, 2013).

Pembelajaran inkuiri juga mengandung prinsip, sebagai suatu pembelajaran yang menekankan kepada pengembangan intelektual anak. Dalam pembelajaran inkuiri terdapat beberapa prinsip yang harus diperhatikan oleh setiap guru, antara lain sebagai berikut 1) Berorientasi pada pengembangan intelektual. Tujuan utama dari pembelajaran inkuiri adalah mengembangkan kemampuan berpikir. Dengan demikian, pembelajaran ini selain berorientasi kepada hasil belajar juga berorientasi pada proses belajar. Karena itu, keberhasilan dari proses pembelajaran dengan menggunakan pembelajaran inkuin bukan ditentukan oleh sejauh mana siswa dapat menguasai materi pelajaran, akan tetapi sejauh mana siswa beraktivitas mencari dan menemukan sesuatu. 2) Prinsip interaksi. Proses pembelajaran pada dasarnya adalah proses interaksi, baik interaksi antara siswa maupun interaksi antara siswa dengan lingkungan Pembelajaran sebagai proses interaksi berarti menempatkan guru sebagai sumber belajar, tetapi sebagai pengatur lingkungan atau pengatur interaksi itu sendiri. 3) Prinsip bertanya. Peran guru yang harus dilakukan dalam menggunakan pembelajaran inkuiri adalah guru sebagai penanya Sebab kemampuan siswa untuk menjawab setiap pertanyaan pada dasarnya sudah merupakan sebagian dari proses berpikir. Oleh sebab itu, kemampuan guru untuk bertanya dalam setiap langkah inkuiri sangat diperlukan. 4) Prinsip belajar untuk berpikir. Proses berpikir (learning how to think), yaitu proses mengembangkan potensi seluruh otak. 5) Prinsip keterbukaan. Belajar adalah proses mencoba berbagai kemungkinan. Segala sesuatu munngkin saja terjadi. Oleh sebau itu anak perlu diberikan kebebasan untuk mencoba sesuai dengan perkembangan kemampuan logika dan nalarnya.

Banks (1990) mengemukakan guru IPS yang menggunakan pendekatan inkuiri bertujuan untuk menghasilkan fakta, konsep, generalisasi, dan teori. Namun, tujuan utama 


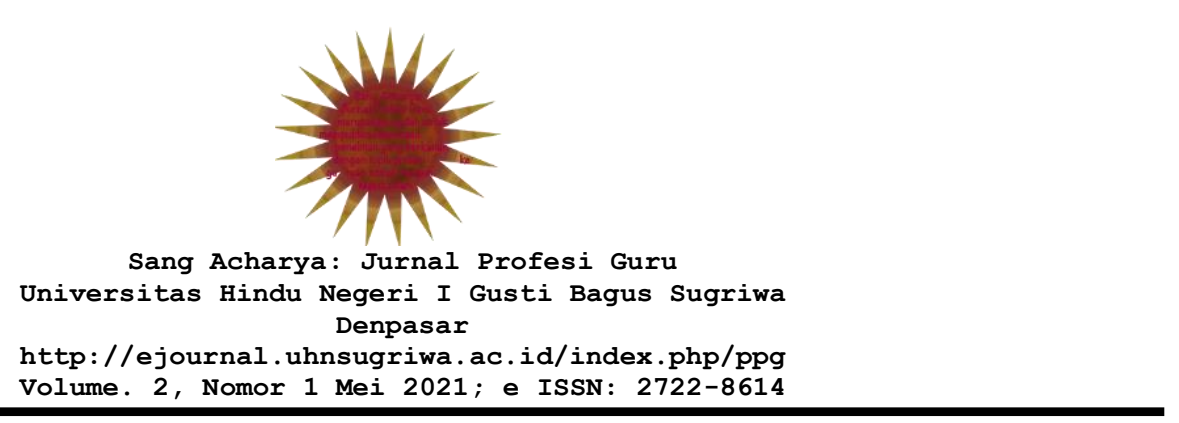

inkuiri sosial menurutnya adalah untuk membangun teori. Para ilmuwan sosial percaya bahwa salah satu cara membantu masyarakat adalah dengan membangun teori. Teori dapat digunakan untuk memahami, menjelaskan, memprediksi, dan mengontrol perilaku masyarakat. Selain itu, tujuan inkuiri sosial pun diharapkan dapat membantu masyarakat dalam memecahkan masalah-masalah sosial sehingga mereka dapat memperoleh kehidupan yang lebih baik. Untuk itu inkuiri sosial seyogianya memberikan prioritas/memfokuskan pada masalah-masalah praktis kemasyarakatan. Dari sudut pandang ini, tujuan utama inkuiri sosial adalah memberikan kontribusi untuk para pengambil kebijakan dalam menghasilkan keputusan-keputusannya.

\subsection{Peran Guru IPS Meningkatkan Kemampuan Berpikir Kritis Siswa}

Keterampilan berpikir menjadi hal penting yang harus dikuasai peserta didik. Ada dua fokus disain pembelajaran keterampilan berpikir, yakni keterampilan berpikir kritis (critical thingking skill) dan keterampilan berpikir kreatif (creative thinking skill). Dua disain pembelajaran ini dapat dipilih oleh guru untuk diterapkan dalam proses belajar mengajar IPS. Prinsip model pembelajaran berpikir kritis dan kreatif ini memiliki beberapa kesamaan dengan inkuiri, yakni sama-sama membantu siswa berlatih dalam berpikir dan memecahkan berbagai masalah kehidupan pribadi siswa maupun masyarakat. Oleh karena itu, pemahaman terhadap model desain pembelajaran inkuiri akan sangat membantu dalam memahami model desain pembelajaran berpikir.

Johnson (1992) merumuskan istilah "berpikir kritis" (critical thinking) secara etimologi. Ia menyatakan bahwa kata "critic" dan "critical" berasal dari kata"krinein", yang berarti "menaksir nilai sesuatu“. Lebih jauh, ia menjelaskan bahwa kritik adalah perbuatan seorang yang mempertimbangkan, menghargai, dan menaksir nilai sesuatu hal. Tugas orang yang berpikir kritis adalah menerapkan norma dan standar yang tepat terhadap suatu hasil dan mempertimbangkan nilainya dan mengartikulasikan pertimbangan tersebut. Ada tiga substansi dari kemampuan berpikir kritis. Pertama, berpikir kritis memerlukan sejumlah kemampuan kognitif, kedua, berpikir kritis memerlukan sejumlah informasi dan pengetahuan; dan ketiga, berpikir kritis mencakup dimensi afektif yang semuanya menjelaskan dan menekankan secara berbeda-beda.

Ennis (1987) menyatakan bahwa berpikir kritis sebagai suatu aktivitas reflektif, demi mencapai tujuan yang memuat keyakinan dan perilaku rasional. Ia pun telah melakukan identifikasi lima kunci unsur berpikir kritis, yakni, "praktis, reflektif, rasional, terpercaya, dan berupa tindakan". Berdasarkan pemikiran tersebut dirumuskan definisi bahwa berpikir kritis merupakan aktivitas berpikir secara reflektif dan rasional yang difokuskan pada penentuan apa yang harus diyakini atau dilakukan. Definisi ini lebih menekankan pada tahapan membuat keputusan atau pertimbangan-pertimbangan. Sementara Lipman (1988) menjabarkan tujuan berpikir kritis yakni untuk menilai suatu pemikiran, menaksir nilai bahkan mengevaluasi pelaksanaan atau praktik dari suatu pemikiran dan nilai tersebut. Selain itu, berpikir kritis meliputi aktivitas mempertimbangkan berdasarkan pada pendapat yang diketahui. 


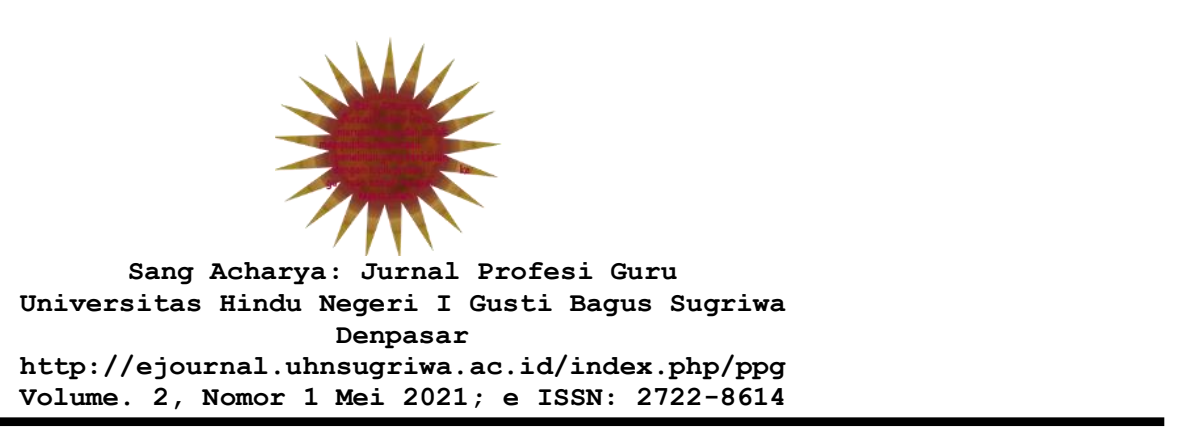

Berpikir kritis mendorong munculnya pemikiran-pemikiran baru. Terkadang, pembelajaran berpikir kritis erat kaitannya dengan berpikir kreatif. Apabila keterampilan berpikir kritis dilakukan maka sebagian dari pembelajaran berpikir kreatif telah dijalani karena tahap pertama untuk melakukan keterampilan berpikir kritis harus melalui keterampilan berpikir kreatif. Tahap awal sebagai syarat untuk memasuki sikap berpikir kritis adalah adanya sikap siswa memunculkan ide-ide atau pemikiran-pemikiran baru. Tahap ini disebut pula tahap berpikir kreatif. Tahap kedua, siswa membuat pertimbangan atau penilaian atau taksiran berdasarkan kriteria yang dapat dipertanggungjawabkan. Tahap kedua inilah yang dikategorikan sebagai tahap berpikir kritis (Armstrong, 1996).

Aziz (2014) merumuskan langkah yang dapat diterapkan guru dalam membangun keterampilan berpikir kritis siswa. Adapun lima tahapan tersebut sebagai berikut. 1) Fokus awal, guru mendorong siswa untuk memikirkan bagaimana cara terbaik untuk memecahkan masalah, misalnya apa yang harus dilakukan agar anak-anak dapat selalu menjaga kebersihan di ruang kelas?. 2) Selanjutnya, guru bertanya mengapa pemikiran untuk memecahkan masalah tersebut belum dilaksanakan?. 3) Setelah siswa menjawab pertanyaan ini, guru menanya siswa lainnya, membantu siswa yang sedang berpikir mengenai langkah mengatasi kesulitan tersebut. 4) Guru lantas meminta siswa memikirkan masalah yang mungkin dihadapi dalam menjawab pertanyaan terdahulu. 5) Akhirnya, siswa diminta menentukan apakah langkah pertama untuk memecahkan masalah. Dalam kondisi ini siswa akan menjawab dan mempertahankan pilihan sesuai dengan kriteria yang ada.

Lima tahapan untuk membangun keterampilan berpikir kritis tersebut menunjukan banyak upaya yang telah dirancang untuk mengembangkan, menggeneralisir dan mempraktikkan kecakapan berpikir kritis di dalam kelas, khususnya dalam proses belajar mengajar studi sosial. Penjabaran tersebut juga menunjukan bahwa pembelajaran inkuiri dan keterampilan berpikir kritis dapat tumbuh subur di kelas ketika guru menilai pemikiranpemikiran yang berbeda, termasuk pemikiran yang berbeda dengan nilai yang dibawa oleh guru dan mendorong siswa untuk berpikir secara bebas. Sementara kondisi saat ini belum banyak muncul kesadaran yang tinggi pada kalangan pendidik di persekolahan, untuk mengajar para peserta didik tentang kondisi dunia yang semakin berkembang pesat, padahal situasi tersebut menuntut adanya respons dengan pemikiran secara kritis. Oleh karena itu, pembelajaran dengan penerapan keterampilan berpikir kritis di kelas merupakan cara yang paling tepat untuk menjawab tantangan ini.

Wilen (1995) menyatakan ada sejumlah teori dan model pengajaran berpikir kritis, yang telah meliputi pendekatan, strategi, perencanaan dan sikap siswa dalam berpikir kritis. Seperti pendekatan metacognitif dalam pengajaran berpikir kritis untuk studi sosial. Pendekatan ini dapat menjadi suatu alternatif untuk mengajar keterampilan berpikir kritis. Pendekata ini juga dapat menjadi satu strategi untuk membantu para siswa mendapatkan keterampilan berpikir kritis melalui penjelasan guru, membuat percontohan atau model oleh guru dan oleh para siswa. Ada pula seperangkat keterampilan berpikir kritis yang dapat digunakan dalam studi sosial. Keterampilan-keterampilan tersebut adalah sebagai berikut. 1) Membedakan antara fakta dan nilai dari suatu pendapat. 2) Menentukan reliabilitas sumber. 


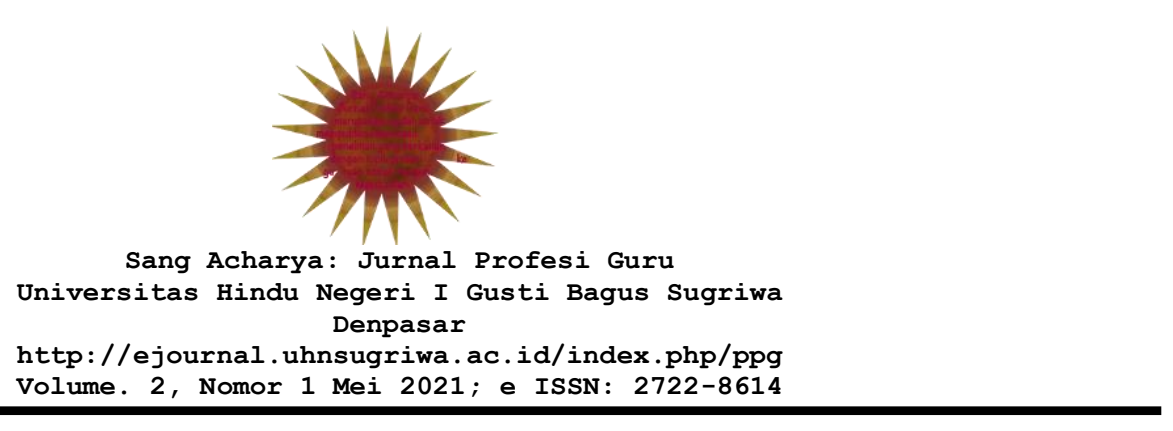

3) Menentukan akurasi fakta dari suatu pernyataan. 4) Membedakan informasi yang relevan dari yang tidak relevan. 5) Mendeteksi penyimpangan. 6) Mengidentifikasi asumsi yang tidak dinyatakan. 7) Mengidentifikasi tuntutan dan argumen yang tidak jelas atau samar-samar. 8) Mengakui perbuatan yang keliru dan tidak konsisten. 9) Membedakan antara pendapatan yang tidak dan dapat dipertanggungjawabkan. 10) Menentukan kekuatan argument.

\section{Kesimpulan}

Berdasarkan uraian pembahasan tersebut, maka dapat diambil beberapa kesimpulan :

a. Mata pelajaran IPS sebagai integrasi utuh dari disiplin ilmu-ilmu sosial dan disiplin ilmu lain yang relevan untuk merealisasikan tujuan pendidikan nasional di tingkat persekolahan. Dalam proses pembelajaran IPS, siswa dapat diajak mengenal lingkungan alam dan masyarakat, sehingga mengetahui realita, masalah serta berbagai fenomena sosial yang terjadi. Proses pembelajaran ini akan membentuk pribadi peserta didik sebagai anggota masyarakat yang baik, dengan mentaati aturan yang berlaku dan turut pula mengembangkannya.

b. Guru IPS yang menggunakan pendekatan ikuiri sosial bertujuan untuk menghasilkan fakta, konsep, generalisasi, dan teori. Model Pembelajaran inkuiri yang menekankan proses berpikir kritis dan analitis, penting untuk mendorong siswa mencari dan menemukan sendiri jawaban dari suatu masalah yang dipertanyakan. Proses berpikir itu sendiri dilakukan melalui tanya jawab antara guru dan siswa. Model Pembelajaran inkuiri dapat menjadi suatu strategi yang berpusat pada peserta didik, dimana kelompok siswa pembelajaran inkuiri diarahkan ke suatu isu atau mencari jawaban-jawaban terhadap isi pertanyaan. Untuk itu inkuiri sosial seyogianya memberikan prioritas/memfokuskan pada masalah-masalah praktis kemasyarakatan. Sejumlah langkah model pembelajaran inkuiri untuk kelas IPS mulai dari: perumusan masalah, perumusan hipotesis, menyusun konsep, pengumpulan data, pengujian dan analisis data, menguji hipotesis, terakhir mengulang proses inkuiri.

c. Berpikir kritis mendorong munculnya pemikiran-pemikiran baru. Tahap awal memasuki sikap berpikir kritis adalah adanya sikap siswa memunculkan ide-ide atau pemikiranpemikiran baru. Tahap ini juga akan diiringi dengan membuat pertimbangan atau penilaian berdasarkan kriteria yang dapat dipertanggungjawabkan. Tahap kedua inilah yang dikategorikan sebagai tahap berpikir kritis. Pembelajaran inkuiri dan keterampilan berpikir kritis dapat berjalan optimal ketika guru menilai pemikiran-pemikiran yang berbeda dan mendorong siswa untuk berpikir secara bebas. 


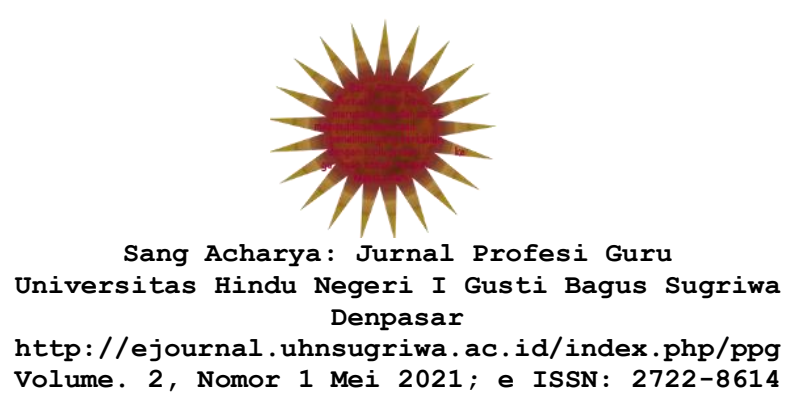

DAFTAR PUSTAKA

Wahab, Abdul Azis. 2014. Konsep Dasar IPS. Tanggerang Selatan: Universitas Terbuka.

Siska, Yulia. 2018. Pembelajaran IPS Di SD MI. Yogyakarta: Garudhawaca

UU No. 20 Tahun 2003 tentang Sistem Pendidikan Nasional.

Sapriya. 2017. Pendidikan IPS. Bandung: Remaja Rosdakarya.

Trianto. 2015. Model Pembelajaran Terpadu. Jakarta: Bumi Aksara

Handayani, Sri. 2014. Peningkatan Kompetensi Pedagogik Guru IPS Sekolah Dasar melalui Penerapan Keterampilan Mengajar. Jurnal Ilmu Pendidikan Dasar.

Marheani. 2013. Landasan dan Inovasi Pembelajaran. Singaraja: Universitas Pendidikan Ganesha.

Nuryati, Lilis. (2018). Analisis Kemampuan Berpikir Kritis Siswa SMP. Jurnal Pendidikan. DOI: http://journal.um.ac.id/index.php/jptpp/article/view/10490/5163

Yuliati, L (2013). Efektivitas Bahan Ajar IPA Terpadu terhadap Kemampuan Berpikir Tingkat Tinggi Siswa SMP. Jurnal Pendidikan Fisika Indonesia. DOI: http://dx.doi.org/10.15294/jpfi.v9il.2580. 